\title{
POTENSI TERTULARNYA IKAN MAS (Cyprinus carpio L.) UMUR YANG BERBEDA TERHADAP Myxobolus koi PADA INFEKSI BUATAN DENGAN METODE TABUR SPORA
}

\section{The Potential Transmission of Carp (Cyprinus Carpio L.) at Different Age Against Myxobolus Koi on the Artificial Infection with the Methods Sow Spores}

Arya Witantama ${ }^{1 *}$, Gunanti Mahasri ${ }^{2}$ dan Sri Subekti ${ }^{3}$.

${ }^{1}$ Program Studi Budidaya Perairan, Fakultas Perikanan dan Kelautan, Universitas Airlangga, Surabaya

${ }^{2}$ Departemen Manajemen Kesehatan Ikan dan Budidaya Perairan, Fakultas Perikanan dan Kelautan, Universitas Airlangga, Surabaya

* arya-w-09@fpk.unair.ac.id

\begin{abstract}
Abstrak
Masalah terbesar yang sering menjadi penghambat budidaya ikan mas adalah munculnya serangan penyakit. Salah satu jenis parasit yang sering menyerang benih ikan mas adalah Myxobolus koi. Myxobolus koi sering menyerang pada ikan stadia benih. Infeksi Myxobolus koi dapat menyebabkan kematian sekitar 50\% dari populasi. Gejala klinis ikan yang terserang Myxobolus koi adalah terdapat nodul yang berisi spora pada organ insang sehingga bagian operculum tidak bisa tertutup dengan sempurna. Pencegahan menjadi jalan terbaik untuk menanggulangi Myxobolusis.

Tujuan dari penelitian ini adalah untuk mengetahui potensi tertularnya ikan mas terhadap Myxobolus koi serta mengetahui potensi tertularnya ikan mas pada umur yang berbeda terhadap Myxobolus koi pada infeksi buatan dengan metode tabur spora.

Metode penelitian yang digunakan adalah metode eksperimental, dengan menginfeksi spora Myxobolus koi dengan metode tabur spora pada ikan mas berumur 30 hari, 60 hari dan 90 hari. Setelah pemeliharan selama 7 hari dilakukan penghitungan spora pada saluran pencernaan ikan. Analisis statistik hasil penelitian menggunakan Analysis of Varian (ANOVA) untuk mengetahui pengaruh perlakuan.

Hasil rata-rata jumlah spora Myxobolus koi di dalam saluran pencernaan ikan didapat pada umur 30 hari 93,5 spora/ml, 60 hari 85,8 spora/ml dan 90 hari $86,7 \mathrm{spora} / \mathrm{ml}$. Hasil analisis varian diperoleh tidak adanya perbedaan nyata antara umur ikan mas terhadap jumlah spora di dalam saluran pencernaan ikan. Dapat disimpulkan bahwa semua stadia umur ikan mas mempunyai potensi tertular Myxobolus koi serta perbedaan umur ikan mas tidak mempunyai potensi yang berbeda tertular Myxobolus koi.
\end{abstract}

Kata Kunci : Myxobolus koi, Ikan Mas, Spora, Nodul

\begin{abstract}
The biggest problem often to be an impediment to the cultivation of carp is the emergence of attack of disease. Any of various parasites that often attacks the carp seed is Myxobolus koi. Myxobolus sp. often attacks on fish stadia seeds. Infection of Myxobolus koi can cause 50\% death of the population. The clinical symptom of Myxobolus koi infected is there a nodule containing spores in gills there for the part of the operculum can't open well. Prevention of disease becomes the best way to control Myxobolusis.
\end{abstract}


The purpose of this research is to know the potential transmission of carp against Myxobolus koi and knowing the potential transmission of carp in different age against artificial infection of Myxobolus koi with the sow spores method.

The method is the experimental methods, infection spores Myxobolus koi with the methods sow spores in carp age of 30 days 60 days and 90 days. After maintenance for 7 days were counted spores in the gastrointestinal tract of fish. Statistical analysis of the results of research using Analysis of Varian (ANOVA) to determine the effect of treatment.

The results of the average number of spores of Myxobolus koi in the fish digestive tract acquired at the age of 30 days 93,5 spores $/ \mathrm{ml}, 60$ days 85,8 spores $/ \mathrm{ml}$ and 90 days 86,7 spores $/ \mathrm{ml}$. The result analysis variant obtained the absence of a real difference between the ages of carp over the amount of spores in the digestive tract fish. It can be concluded that all the stadia age carp have the potential of contracting Myxobolus koi and carp age difference does not have a different potential contracted Myxobolus koi.

Key Word : Myxobolus koi, Carp, Spores, Nodules

\section{PENDAHULUAN}

Khairuman (2008) mengemukakan bahwa budidaya ikan mas memiliki beberapa keunggulan yaitu dapat dibudidayakan dengan padat penebaran yang tinggi, responsif terhadap makanan, pertumbuhannya cepat dan harganya stabil. Data produksi ikan mas pada tahun 2005 sebanyak 216.920 ton meningkat pada tahun 2009 sebanyak 446.800 ton (Dinas Kelautan dan Perikanan, 2009). Menurut Handajani (2005) masalah terbesar yang sering dianggap menjadi penghambat budidaya ikan mas adalah munculnya serangan penyakit. Penyakit pada ikan secara umum dapat menyebabkan terhambatnya pertumbuhan, periode pemeliharaan lebih lama, tingginya konversi pakan, tingkat padat tebar yang rendah. Salah satu jenis parasit yang sering menyerang benih ikan mas adalah Myxobolus koi. Myxobolus merupakan parasit yang bersifat sistemik dan dapat menimbulkan kerugian bagi usaha budidaya ikan. Parasit ini sering dijumpai menjadi penyebab penyakit pada ikan mas (Helmiati dkk., 2005).

Djajadiredja dkk. (1982) melaporkan bahwa pada tahun 1951 di Jawa Tengah terjadi wabah Myxobolus pyriformmis yang telah membunuh banyak benih ikan mas dan menyebabkan kerugian se- tiap tahun. Hasil penelitian Dewi (2010), pada tahun 2002 telah terjadi kematian masal ikan mas di daerah Sleman dan Kulon Progo yang disebabkan oleh myxobolus koi dan Henneguya sp. Sehingga kerugian yang dialami pembudidaya ikan cukup besar. Prevalensi Myxobolus koi pada ikan mas menunjukkan angka yang cukup tinggi yaitu 61,67\%. Мyxobolus koi sering menyerang pada ikan stadia benih, sehingga hal tersebut menyebabkan benih lebih rentan terserang Myxobolus koi daripada ikan dewasa. Infeksi Myxobolus koi dapat menyebabkan kematian sekitar 50\% dari populasi (Mulyana dkk., 1990).

Menurut Wellby et al. (2005) gejala klinis pada ikan yang terserang Myxobolus koi adalah terdapat nodul yang berisi spora pada organ insang sehingga bagian operculum tidak bisa tertutup dengan sempurna. Nodul berbentuk bulat telur dan berwarna putih kekuningan. Lom dan Dykova (1992) menjelaskan dalam satu nodul ukuran kecil berisi spora Myxobolus koi paling sedikit berjumlah 15.000. Bila nodul ini sudah matang, maka spora akan mencemari perairan dan akan termakan oleh ikan.

Bertitik tolak dari latar belakang tersebut, maka perlu adanya pemeriksaan ikan yang terserang Myxobolus koi untuk

Diterima/submitted:29 September 2014

Disetujui/accepted:21 Maret 2016 
mengetahui jumlah spora yang tertelan masuk hingga ke dalam usus melalui penularan secara buatan yaitu dengan tabur spora.

\section{METODOLOGI \\ Waku dan Tempat}

Pengambilan sampel penelitian dilakukan di kolam budidaya petani ikan di desa Kemloko, Kecamatan Nglegok, Kabupaten Blitar. Identifikasi Myxobolus koi dan penghitungan spora pada usus ikan dilaksanakan di Fakultas Perikanan dan Kelautan Universitas Airlangga Surabaya. Penelitian ini dilaksanakan pada bulan Agustus - Oktober 2013.

\section{Materi Penelitian}

Peralatan Penelitian

Peralatan penelitian yang dibutuhkan antara lain 18 akuarium ukuran 40×25×25 $\mathrm{cm}^{3}$ untuk pemeliharaan ikan mas. Sedangkan untuk akuarium stock menggunakan bak plastik. Penghitungan spora dalam usus spora menggunakan alat antara lain microscope, haemocytometer, tabung sentrifus, sentrifus, kertas saring, kaca pembesar, pipet, handtally counter. Peralatan untuk pengukuran kualitas air antara termometer untuk pengukuran suhu, $\mathrm{pH}$ paper untuk pengukuran keasaman $(\mathrm{pH})$, test kit DO dan amonia.

Bahan Penelitian

Myxobolus koi didapat dari ikan yang positif myxobolusis. Pemeriksaan penelitian ini dilakukan pada ikan yang berumur 30 hari, 60 hari dan 90 hari yang diinfestasi Myxobolus koi untuk membandingkan jumlah spora di dalam saluran pencernaan pada benih, ikan muda dan ikan dewasa umur. Masing-masing perlakuan umur berjumlah 6 ekor. Ikan mas ini didapat dari kolam budidaya di Kabupaten Blitar. Bahan yang digunakan dalam penelitian ini adalah usus ikan mas (Cyprinus carpio L.) yang terserang Myxobolus $k o i$, PBS dan aquades.

\section{Metode Penelitian}

Metode penelitian yang digunakan adalah metode eksperimental yang bertujuan meneliti pengaruh perlakuan terhadap perilaku yang timbul sebagai akibat perlakuan (Alsa, 2004).

\section{Prosedur Kerja}

Akuarium terlebih dahulu dicuci bersih dan masing-masing dilanjutkan dikeringkan di bawah sinar matahari. Air dimasukkan ke dalam akuarium sebanyak 10 liter dan diaerasi selama 24 jam.

Ikan mas yang positif terinfestasi Myxobolus koi diperoleh dari kolam di desa Kemloko, Kecamatan Nglegok, Kabupaten Blitar. Tiap akuarium diisi 3 ekor ikan kemudian ikan dipelihara 7 hari dan diamati perkembangan spora dari tertelannya oleh ikan sampai dengan pemeriksaan spora pada saluran pencernaan ikan.

Lom and Dykova (1992) menyatakan bahwa pemeriksaan dapat dilakukan dengan pengamatan organ target dan identifikasi melalui karakteristik My-xobolus koi. Karakteristik morfologi spora Myxobolus koi dapat dikenali berdasarkan bentuk spora, bagian dalam dari kapsul polar dan jumlah kapsul polar. Pemeri-ksaan spora dapat dilakukan secara lang-sung dengan mikroskop pembesaran 400x. Cara identifikasi dengan cara melakukan pembedahan usus ikan mas dan dilakukan pemeriksaan dengan metode natif dan metode konsentrasi. Metode konsentrasi dilakukan apabila metode natif belum dapat menemukan Myxobolus koi (Mahasri dkk. 2008).

Parameter utama yang diamati adalah potensi tertularnya ikan mas yang dinyatakan sebagai jumlah spora yang ditemukan di dalam usus ikan. Penghitungan jumlah spora yang tertelan dalam usus yaitu ikan yang positif terinfeksi $M y$ xobolus koi dilakukan pembedahan untuk diperiksa jumlah spora yang tertelan dalam usus. Suspensi yang ada dalam usus diambil sebanyak 1 gram dan diaduk dalam 
$10 \mathrm{ml}$ air kemudian disaring kertas saring berukuran $1 \mu \mathrm{m}$. Hasil saringan dimasukkan dalam tabung centrifuge sampai dengan $1 \mathrm{~cm}$ di bawah permukaan tabung. Tabung dan isinya diputar (sentrifuge) selama 2-3 menit dengan kecepatan 1500 rpm.

Supernatan yang terbentuk dibuang dan endapan ditinggalkan sebanyak $\pm 1 \mathrm{~cm}$ dari dasar tabung dan diputar kembali selama 2-3 menit dengan kecepatan 1500 rpm. Selanjutnya supernatan dibuang dan endapan ditambahkan PBS sampai volume dua kalinya. Penghitungan jumlah spora dilakukan menggunakan mikroskop dengan pembesaran 400x (Satyantini dan Masitha. 2007).

Parameter penunjang penelitian berupa kualitas air yang meliputi suhu, oksigen terlarut, amonia, dan $\mathrm{pH}$ diukur selama penelitian. Pengukuran suhu dengan termometer, pengukuran oksigen terlarut dengan menggunakan DO Test Kit, $\mathrm{pH}$ dengan $\mathrm{pH}$ paper, dan pengukuran amonia menggunakan Amonia Tes Kit. Pengukuran parameter kualitas air akuarium penelitian dilakukan dua kali yaitu pada awal dan akhir perlakuan.

\section{HASIL DAN PEMBAHASAN \\ Identifikasi Spora Myxobolus koi}

Ikan mas yang digunakan adalah ikan mas yang berumur 30 hari, 60 hari dan 90 hari yang diinfeksi spora Myxobolus koi sebanyak 80 spora/liter. Penghitungan jumlah spora dilakukan 7 hari setelah ikan diberi infeksi spora Myxobolus koi. Setiap perlakuan umur dilakukan enam kali ulangan.

Identifikasi spora Myxobolus koi dilakukan pada saluran pencernaan ikan mas. Spora Myxobolus koi yang ditemukan berbentuk oval, mempunyai sporoplasma dan memiliki dua kapsul polar yang masing-masing di dalamnya terdapat filamen polar. Ini sesuai dengan pendapat Lom and Dyková (2006) yang menyebutkan bahwa spora Myxobolus koi ber- bentuk oval atau bulat telur, dua kapsul polar terdapat filamen polar di dalamnya.

\section{Gejala Klinis Ikan Mas Pada Saat Pemeliharaan}

Ikan mas yang telah diberi perlakuan, diamati tingkah laku dan gejala klinisnya selama masa pemeliharaan satu minggu. Hasil dari pengamatan gejala klinis dan tingkah laku ikan mas pada saat satu minggu pemeliharaan dapat dilihat pada Tabel 1.

\section{Penghitungan Jumlah Spora}

Hasil penghitungan jumlah ratarata spora yang ditemukan pada saluran penncernaan ikan setelah diinfeksi Myxobolus koi dapat dilihat pada Tabel 2.

Hasil rata-rata jumlah spora Myxobolus koi di dalam saluran pencernaan ikan mas pada ke tiga perlakuan diketahui umur 30 hari memiliki jumlah rata-rata spora tertinggi yaitu dengan jum-lah rata-rata spora 93,5 spora/ml. Kemu-dian umur 90 hari memiliki jumlah rata-rata spora tertinggi kedua dengan jumlah rata-rata spora $86,7 \mathrm{spora} / \mathrm{ml}$. Umur 60 hari memiliki jumlah rata-rata spora teren-dah dengan jumlah rata-rata spora 85,8 spora/ml. Hasil analisis varian diperoleh tidak adanya perbedaan yang nyata antara umur ikan mas terhadap jumlah spora di dalam saluran pencernaan $(\mathrm{F}$. hitung $<\mathrm{F}$. tabel $5 \%$ ).

\section{Kualitas Air}

Pengukuran parameter kualitas air akuarium penelitian dilakukan 2 kali yaitu pada awal dan akhir perlakuan.. Kisaran kualitas air pada awal dan akhir pemeliharaan dapat dilihat pada Tabel 3.

\section{Pembahasan}

Myxobolus sering dijumpai menjadi penyebab penyakit pada ikan mas dan dapat menimbulkan kerugian bagi usaha budidaya ikan (Helmiati dkk., 2005). Dengan jumlah spora yang diinfeksikan 80 spora/liter diketahui bahwa umur 30 hari mempunyai jumlah rata-rata 
spora Myxobolus koi tertinggi, kemudian diikuti umur 90 hari dan 60 hari. Dari hasil tersebut diketahui bahwa umur 30 hari mempunyai jumlah rat-rata sp. sering menyerang pada ikan stadia benih. Tetapi jumlah rata-rata spora antara umur 30 hari, 60 hari dan 90 hari tidak mempunyai perbedaan yang signifikan. Ini

Tabel 1. Hasil Pengamatan Ikan Mas Selama Satu Minggu Perlakuan

\begin{tabular}{|c|c|c|c|}
\hline \multirow[t]{2}{*}{ Hari Ke- } & \multicolumn{3}{|c|}{ Gejala Klinis / Tingkah Laku Ikan Selama Perlakuan } \\
\hline & 30 hari & 60 hari & 90 hari \\
\hline 1 & Ikan masih sehat & Ikan masih sehat & Ikan masih sehat \\
\hline 2 & Ikan masih sehat & Ikan masih sehat & Ikan masih sehat \\
\hline 3 & Ikan masih sehat & Ikan masih sehat & 2 ikan berenang lambat \\
\hline 4 & $\begin{array}{c}\text { Nafsu makan mulai } \\
\text { menurun }\end{array}$ & $\begin{array}{l}\text { Nafsu makan mulai } \\
\text { menurun }\end{array}$ & $\begin{array}{l}\text { Nafsu makan mulai menurun } \\
\text { dan beberapa ikan cenderung } \\
\text { diam di dasar akuarium }\end{array}$ \\
\hline 5 & $\begin{array}{c}\text { Beberapa ikan } \\
\text { berenang lambat }\end{array}$ & $\begin{array}{c}\text { Beberapa ikan } \\
\text { berenang lambat dan } \\
\text { ada beberapa ikan } \\
\text { yanng cenderung diam } \\
\text { di dasar akuarium }\end{array}$ & $\begin{array}{l}\text { Buka tutup operculum } \\
\text { beberapa ikan mulai melambat } \\
\text { dan semua ikan cenderung } \\
\text { diam di dasar akuarium }\end{array}$ \\
\hline 6 & $\begin{array}{c}\text { Hampir semua ikan } \\
\text { cenderung diam di } \\
\text { dasar akuarium dan } \\
\text { buka tutup } \\
\text { operculum } \\
\text { melambat }\end{array}$ & $\begin{array}{c}\text { Hampir semua ikan } \\
\text { cenderung diam di } \\
\text { dasar akuarium dan } \\
\text { buka tutup operculum } \\
\text { melambat }\end{array}$ & $\begin{array}{l}\text { Semua ikan tampak stres dan } \\
\text { melemah. }\end{array}$ \\
\hline 7 & $\begin{array}{l}\text { Semua ikan tampak } \\
\text { stres dan melemah. }\end{array}$ & $\begin{array}{l}\text { Semua ikan tampak } \\
\text { stres dan melemah. }\end{array}$ & $\begin{array}{l}\text { Semua ikan tampak stres dan } \\
\text { melemah. Tubuh dan insang } \\
\text { ikan tampak pucat. }\end{array}$ \\
\hline
\end{tabular}

Tabel 2. Jumlah Rata-Rata Spora Myxobolus koi Pada Saluran Pencernaan Ikan Mas

\begin{tabular}{cc}
\hline Perlakuan Umur Ikan (hari) & Rata-rata (spora/ml) \\
\hline 30 & $93,5^{\mathrm{a}}$ \\
60 & $85,8^{\mathrm{a}}$ \\
90 & $86,7^{\mathrm{a}}$ \\
\hline
\end{tabular}

Tabel 3. Kisaran Kualitas Air Media Pemeliharaan Ikan Mas Pada Awal Dan Akhir Pemeliharaan

\begin{tabular}{clcc}
\hline No. & \multicolumn{1}{c}{ Parameter } & Satuan & Kisaran \\
\hline 1 & Suhu & $\mathrm{C}$ & $26-27$ \\
2 & Keasaman $(\mathrm{pH})$ & - & $7-8$ \\
3 & Oksigen terlarut & $\mathrm{mg} / \mathrm{L}$ & $2-5$ \\
4 & Amoniak & $\mathrm{mg} / \mathrm{L}$ & $0,25-1,5$ \\
\hline
\end{tabular}

spora tertinggi dibandingkan dengan umur 60 hari dan 90 hari. Ini sesuai dengan pendapat Dewi (2010) bahwa Myxobolus menjelaskan bahwa semua stadia umur ikan mas mempunyai potensi untuk tertular Myxobolus koi. 
Hasil analisis varian diperoleh tidak adanya perbedaan yang nyata antara umur ikan mas terhadap jumlah spora di dalam saluran pencernaan, sehingga penelitian ini menunjukkan bahwa umur ikan mas tidak mempunyai potensi yang berbeda terhadap tertularnya Myxobolus koi. Ini tidak sesuai dengan pendapat Dewi (2010) yang menyatakan bahwa benih lebih rentan terserang Myxobolus sp. daripada ikan dewasa. Hal ini menjelaskan bahwa tidak benih saja yang rentan terserang Myxobolus koi tetapi ikan pada semua stadia umur yang lainnya juga rentan terserang Myxobolus koi.

Meskipun di antara ketiga umur perlakuan mempunyai potensi yang sama terinfeksi myxobolusis tapi tidak serta merta derajat infeksi ketiga umur ikan tersebut sama. Hal ini disebabkan spora yang masih berada di saluran pencernaan belum menembus dinding usus menuju organ target melalui saluran darah. Bisa saja sebagian dari spora tersebut tercerna oleh ikan dan keluar melalui feses. Perlu adanya penelitian lanjutan untuk mengetahui apakah umur ikan mempunyai pengaruh terhadap derajat infeksi Myxobolus koi.

Hasil di atas tersebut juga dipengaruhi oleh kualitas air akuarium perlakuan. Menurut Zonneveld et al. (1991) air merupakan media internal dan eksternal bagi ikan. Sebagai media internal, air berfungsi sebagai bahan baku untuk reaksi di dalam tubuh, pengangkut bahan makanan ke seluruh tubuh, pengangkut sisa metabolisme untuk dikeluarkan dari dalam tubuh dan pengatur suhu tubuh. Sebagai media eksternal, air berfungsi sebagai habitat ikan. Kualitas air merupakan salah satu faktor yang mempengaruhi tingkat kelangsungan hidup dan pertumbuhan ikan selama pemeliharaan. Kualitas air yang harus diperhatikan supaya ikan dapat tumbuh dan berkembang secara optimal adalah suhu, keasaman $(\mathrm{pH})$, oksigen terlarut dan amoniak.
Suhu air selama penelitian berkisar antara $26-27^{\circ} \mathrm{C}$. . Hal ini sesuai dengan pendapat Khairuman dkk. (2008) bahwa suhu air optimal yang dibutuhkan ikan mas yaitu berkisar antara $25-30{ }^{\circ} \mathrm{C}$. Dengan demikian suhu media pemeliharaan masih memenuhi persyaratan.

Derajat Keasaman $(\mathrm{pH})$ air selama penelitian berkisar antara $7-8$. Hal ini sesuai dengan pendapat Susanto (2007) bahwa kisaran $\mathrm{pH}$ yang diperlukan oleh ikan mas berkisar antara $7-9$. Dengan demikian $\mathrm{pH}$ pada media pemeliharaan masih memenuhi persyaratan.

Oksigen merupakan satu parameter yang sangat penting bagi selurah organisme dalam kehidupannya, dimana oksigen sangat diperlukan untuk pernapasan dan metabolisme ikan. Oksigen terlarut (DO) dalam media air selama penelitian berkisar antara $2-5 \mathrm{mg} / \mathrm{l}$. Hal ini sesuai dengan pendapat Khairuman dan Amri (2003) bahwa oksigen terlarut yang dibutuhkan dalam budidaya ikan minimal $3 \mathrm{mg} / \mathrm{l}$. Dengan demikian oksigen terlarut dalam media pemeliharaan tidak memenuhi persyaratan.

Konsentrasi amoniak selama penelitian berkisar antara 0,25-1,5 mg/l. Khairuman dan Amri (2003) menyatakan bahwa batas amoniak dalam perairan yang dapat membahayakan ikan apabila kadar amoniaknya melebihi $0,5 \mathrm{mg} / \mathrm{l}$ air. Dengan demikian kandungan amoniak dalam media pemeliharaan tidak memenuhi persyaratan bagi kehidupan benih ikan mas.

Dengan kualitas air yang kurang mendukung untuk kehidupan ikan mas tersebut menjadi salah satu faktor semua stadia umur ikan tertular Myxobolus koi. Hal ini juga dimungkinkan menjadi salah satu faktor perbedaan umur ikan mas tidak mempunyai potensi yang berbeda terhadap tertularnya Myxobolus koi.

\section{KESIMPULAN DAN SARAN Kesimpulan}

Berdasarkan hasil penelitian, maka dapat diambil kesimpulan bahwa :

Diterima/submitted:29 September 2014 Disetujui/accepted:21 Maret 2016 
1) Ikan mas (Cyprinus carpio L.) mempunyai potensi tertular Myxobolus koi pada infeksi buatan dengan metode tabur spora. Semua stadia umur mempunyai potensi tertular Myxobolus koi dengan terdapatnya spora pada saluran pencernaan ikan mas baik pada umur 30 hari, 60 hari maupun 90 hari.

2) Umur ikan mas (Cyprinus carpio L.) tidak mempunyai potensi yang berbeda terhadap infeksi Myxobolus koi pada infeksi buatan dengan metode tabur spora. Dari analisis data umur ikan mas tidak mempunyai perbedaan nyata terhadap tertularnya Myxobolus koi.

\section{Saran}

Berdasarkan hasil penelitian yang dilakukan, penulis menyarankan bahwa dalam budidaya ikan mas perlu dilakukan pencegahan terhadap serangan Myxobolus koi baik pada stadia benih maupun stadia selanjutnya. Karena semua stadia umur ikan mas mempunyai potensi yang sama terhadap tertutularnya Myxobolus koi. Selain itu, perlu dilakukan penelitian lebih lanjut apakah umur ikan mempunyai derajat infeksi berbeda terhadap Myxobolus koi.

\section{DAFTAR PUSTAKA}

Alsa, A. 2004. Pendekatan Kuantitatif Kualitatif dalam Penelitian Psikologi. Pustaka Pelajar. Yogyakar-ta.

Dewi, T.C. 2010. Studi Myxobolus sp. Pada Ikan Mas (Cyprinus carpio) Secara Konvensional Dan Scanning Electron Microscope (SEM). Tesis. Universitas Gadjah Mada. Jogjakarta

Djajadiredja, R., T.H. Panjaitan, A. Rukyani, A. Sarono, D. Satyani and H. Supriyadi. 1982. Fish quarantine and fish disease in southeast asia. Report of a workshop 7-10 Dec 1982 held in Jakarta. $19-21$.

Handajani, H \& Samsundari, S. 2005. Parasit dan Penyakit Ikan. UMM Press, Muhammadiyah Malang.
Helmiati, S., Triyanto, dan H.N. Kamiso. 2005. Prevalensi dan derajat Infeksi Myxobolus sp. Pada Insang Benih Karper (Cyprinus carpio L.) Di KabupatenSleman Jawa Tengah. 47-53

Khairuman, S.P., D. Sudenda, B. Gunadi. 2008. Budi Daya Ikan Mas Secara Intensif. AgroMedia Pustaka. Jakarta.

Khairuman dan K. Amri. 2003. Budidaya Ikan Nila Secara Intensif. Agromedia Pustaka. Depok.

Lom, J. and I. Dykova. 2006. Myxozoa Genera: Definition and Notes on Taxonomy, Life-Cycle Terminology and Pathogenic Species. Folia Parasitological 53: 1-36.

Lom, J. and I. Dykova. 1992. Protozoan Parasites of Fishes. Developments in Aquaculture and Fisheries Science, Vol.26.Elsevier. 315 pp.

Mahasri, G. dan Kismiyati. 2008. Buku Ajar Parasit dan Penyakit Ikan I (Ilmu Penyakit Protozoa pada Ikan dan Udang). Fakultas Perikanan dan Kelautan Universitas Airlangga. Surabaya. 38-42.

Mulyana, R.I. Riadi, S.L. Angka, A. Rukyani, 1990. Pemakaian Sistem Saringan Untuk Mencegah Infeksi Parasit Pada Benih Ikan Mas ( $C y$ prinus carpio L.) Di Kolam. Prosiding Seminar II Penyakit Ikan dan Udang. Balai Penelitian Perikanan Air Tawar, Pusat Penelitian dan Pengembangan Perikanan, Badan Penelitian dan Pengembangan Pertanian. Bogor. 169 - 173.

Satyantini, W.H. dan E.D. Masitha. 2007. Diktat Penuntun Praktikum Budidaya Pakan Alami. Universitas Airlangga. Surabaya.

Susanto, H. 2007. Budidaya Ikan di Pekarangan. Penebar Swadaya. Jakarta.

Welby. I., D. Hoole, D. Bucke and P. Purgess. 2001. Infectious Disease parasite. 
In Hoole. D, Bucke. D, Purgess. P., Welby. I (eds) Disease of Carp and other Cyprinid Fishes. Chap 5 Blackwell Science. Oxford, P 63 124.

Zonneveld, N., E. A. Huisman dan J. H. Boon. 1991. Prinsip-prinsip Budidaya Ikan. PT Gramedia Pustaka Utama. Jakarta. hal. 48-90. 